\title{
Redactioneel
}

\section{Integratie, coördinatie, klimaat en energie: instrumenten voor uitdagende doelstellingen}

\author{
Mr. dr. V.M.Y. (Valérie) van 't Lam*
}

De bijdragen van dit nummer zien op integratie van regelgeving in het omgevingsrecht, coördinatie van besluitvorming in het bestuursrecht, de klimaatagenda in het waterrecht en de ruimtelijke dimensie van energietransitie. Uitdagende thema's waarin de komende tijd veel ontwikkelingen zullen plaatsvinden.

Uit de bijdrage van Lidia Palm en Wilco de Vos blijkt dat 2018 een belangrijk jaar zal zijn voor de stelselherziening in het omgevingsrecht. Omdat steeds meer stukjes van de puzzel van het nieuwe stelsel op hun plek gaan vallen, kunnen partijen in de praktijk zich beter en gerichter voorbereiden op de inwerkingtreding van het stelsel op 1 januari 2021. Zo zullen bijvoorbeeld op korte termijn de AMvB's in het Staatsblad worden gepubliceerd en zal het advies van de Raad van State over de ontwerp-AMvB's en de ontwerp-Invoeringswet Omgevingswet samen met de reactie van de regering daarop bekend worden.

In 'De betekenis van het Interbestuurlijk Programma voor het waterbeheer' bespreekt Herman Havekes wat de betekenis is van het Interbestuurlijk Programma (IBP) voor het waterbeheer. Het IBP legt de basis voor interbestuurlijke samenwerking. Voor het waterbeheer en de waterschappen gaat het dan om de klimaatagenda, toekomstbestendig wonen, vitaal platteland, regionale economie, goed openbaar bestuur en passende financiële verhoudingen.

Nard Beurskens, Jelmer Ypinga en Kars de Graaf gaan in hun bijdrage 'De Omgevingswet als aanjager voor een nieuwe coördinatieregeling in de Awb' in op de huidige

* Mr. dr. V.M.Y. van 't Lam is advocaat bij Stibbe te Amsterdam en lid van de redactie van het Tijdschrift voor Omgevingsrecht. algemene coördinatieregeling in de Algemene wet bestuursrecht (Awb), de bestaande coördinatieregeling van de Wet ruimtelijke ordening (Wro) en de nieuwe voorgestelde coördinatieregeling in de Awb. Zij bespreken de voorgenomen regeling in de Awb in het algemeen en twee relevante aspecten, te weten de mogelijkheid om de coördinatie van besluitvorming in verschillende fasen uit te voeren en de bevoegdheid van het coördinerende bestuursorgaan om onder omstandigheden te voorzien in besluitvorming in plaats van het oorspronkelijk bevoegde gezag.

Fons van der Linden en Sanne Akerboom gaan in hun bijdrage 'Ruimtelijk beleid voor de energietransitie: centraal wat moet? Een studie naar het omgevingsrechtelijk overheidsinstrumentarium in de energietransitie' in op het verband tussen energietransitie en het omgevingsrecht. Daarbij staat de vraag centraal hoe de keuze voor groot- of kleinschalige maatregelen het omgevingsrechtelijk kader en de ruimte voor een lokale ruimtelijke afweging kan beinvloeden. Daarbij bekijken zij twee transitiepaden: windenergie op land (als onderdeel van het verduurzamen van de elektriciteitsproductie) en de verduurzaming van ruimteverwarming en warm tapwater in de gebouwde omgeving.

In een aantal bijdragen worden ontwikkelingen op het gebied van klimaat en energie benoemd. Op 12 juni 2018 heeft minister Wiebes de Tweede Kamer geïformeerd over de voortgang van het Nationaal Klimaatakkoord. ${ }^{1}$ Om de doelstellingen van het Akkoord van

1. Brief van de minister van Economische Zaken en Klimaat d.d. 12 juni 2018. Zie eveneens over de aanpak van het Klimaatakkoord de brief d.d. 23 februari 2018, Kamerstukken II 2017/18, 32 813, nr. 163. Zie over de kaders voor klimaatbeleid: T. Smolders, Kaders voor klimaatbeleid. De stand van het klimaatbeleid in het eerste kwartaal van 2018, Bb $2018 / 30$ 
Parijs $^{2}$ te halen streeft de Nederlandse regering naar een vermindering van de nationale uitstoot van broeikasgassen met $49 \%$ in 2030, vergeleken met de emissies in $1990 .{ }^{3}$ Om dit doel te bereiken heeft de regering aangegeven dat zij voornemens is een Nationaal Klimaatakkoord aan te gaan met private en (semi)publieke organisaties (hierna: Klimaatakkoord). ${ }^{4}$

Er zijn zogenoemde sectortafels gevormd. ${ }^{5}$ Deze vormen in wezen het hart van het Klimaatakkoord. De sectortafels corresponderen met de vijf sectoren waarvoor reductieopgaven uit het regeerakkoord en Energieakkoord zijn opgenomen: (1) industrie (14,3 Mton), (2) mobiliteit (7,3 Mton, waarvan een resultaatsverplichting van 5,9 Mton), (3) de gebouwde omgeving (3,4 Mton), (4) elektriciteit (20,2 Mton) en (5) landbouw en landgebruik (3,5 Mton $\mathrm{CO}_{2}$ en $\mathrm{CO}_{2}$-equivalenten). ${ }^{6}$ De stakeholders van de sector (zoals nationale en regionale autoriteiten, relevante bedrijven, maar ook milieuorganisaties) zijn vertegenwoordigd in de sectororganen. De instanties moeten overeenstemming bereiken over de belangrijkste overeenkomsten en specifieke reductieverbintenissen. Per sector kunnen subinstanties en/of werkgroepen worden geinstalleerd voor specifieke gebieden of onderwerpen. Elke sectortafel wordt voorgezeten door een onafhankelijke voorzitter en heeft twee secretarissen: een van de SER en een van het eerstverantwoordelijke departement. De algehele voortgang van de onderhandelingen over het Klimaatakkoord en de voortgang van de onderhandelingen in elke sectortafel worden gemonitord door het Klimaatberaad.

Blijkens de brief van 12 juni 2018 is het streven dat het voorstel voor de hoofdlijnen van een Klimaatakkoord medio juli wordt gepresenteerd. Dit voorstel bevat een pakket van mogelijke maatregelen waarvoor de direct betrokken partijen zich hard willen maken. Dat wordt dan onder meer aan het Planbureau voor de Leefomgeving (PBL) gestuurd om gedurende de zomermaanden te worden doorgerekend. Het is de verwachting dat er eind 2018 een Klimaatakkoord is. Dan zal ook op basis van de uitwerking van het Klimaatakkoord een conceptIntegraal Energie- en Klimaatplan (INEK) worden opgesteld door het kabinet. Het concept-INEK wordt gemaakt in het kader van de Europese Energie Unie en de doelen die daarin zijn gesteld. ${ }^{7}$ Wat de verhouding is

2. Overeenkomst van Parijs, Trb. 2016, 162

3. In het regeerakkoord staat dat er een 'Nationaal Klimaat- en Energieakkoord' komt. 'Vertrouwen in de toekomst'. Regeerakkoord 2017-2021 VVD, CDA, D66 en ChristenUnie, Kamerstukken II 2017/18, 34 700, nr. 34. Het belangrijkste broeikasgas is koolstofdioxide $\left(\mathrm{CO}_{2}\right)$. Daarom richt het Klimaatakkoord zich vooral op het verminderen van de $\mathrm{CO}_{2}$ uitstoot in de lucht.

4. Zie over het Klimaatakkoord ook www.klimaatakkoord.nl.

5. Op 17 mei 2018 is als bijlage een overzicht gestuurd van alle sectortafels, subtafels en werkgroepen die actief zijn onder het Klimaatakkoord (Kamerstukken II 2017/18, 32 813, nr. 190).

6. Kosten energie- en klimaattransitie in 2030 - update 2018, PBL 20 maart 2018.

7. Klimaat- en energieplannen zullen voor lidstaten worden verplicht op grond van de Governance Verordening, waartoe een voorstel is gedaan door de Commissie, COM(2016)759 def. Brief van de minister van Economische Zaken en Klimaat d.d. 12 juni 2018. van het Klimaatakkoord met de door de regering op te stellen Klimaatwet is mij niet precies duidelijk. ${ }^{8}$ Uit een brief van de minister van Economische Zaken en Klimaat (EZK) van 8 december 2017 maak ik op dat de Klimaatwet (mede aan de hand van het klimaatplan zoals nu voorgesteld) de hoofdlijnen van het klimaatbeleid zal behelzen (vanuit de overheid), terwijl het akkoord meer de vorm heeft van afspraken tussen alle betrokken partijen (in feite een soort convenant). ${ }^{9}$

In de Kamerbrief van 12 juni 2018 wordt terecht 'belemmerende wet- en regelgeving' als dwarsdoorsnijdend thema aan het Klimaatakkoord toegevoegd. Alle sectortafels wordt gevraagd ook te kijken naar die weten regelgeving die nodig is om de opgave te halen en die passen in de langetermijntransitie. Daarbij gaat het zowel om bestaande wet- en regelgeving die in de huidige vorm een belemmering vormt, alsook om nieuwe wet- en regelgeving die noodzakelijk wordt geacht om de opgave te realiseren. ${ }^{10}$ Voor zover mij bekend is er vooralsnog geen overkoepelend onderzoek gedaan naar de vraag of de huidige wetgeving het bereiken van klimaatdoelen belemmert en/of stimuleert. In dit verband verwijs ik naar een verslag van de Raad van State van de expertbijeenkomst, die plaatsvond bij de Raad van State, over het klimaatbeleid. Centraal stond de vraag welke instrumenten de overheid ter beschikking staan bij het realiseren van de klimaatdoelen, de bruikbaarheid in dat verband van de Klimaatwet en de plaats van bestuurlijke en maatschappelijke akkoorden. Daar is onder andere geadviseerd om na te gaan of er thans regelgeving is die het behalen van klimaatdoelen kan belemmeren, omdat deze bijvoorbeeld een onbedoeld (neven)effect heeft. ${ }^{11}$ In een eerder redactioneel heb ik uiteengezet dat de bestaande wet- en regelgeving ten aanzien van klimaat en energie versnipperd is en dat deze voor zover het om plaatsgebonden activiteiten gaat mogelijk kan worden geïntegreerd in de Omgevingswet. Op termijn moet worden bedacht in hoeverre het zinvol is om de reikwijdte van de Omgevingswet te verruimen tot nietplaatsgebonden activiteiten. ${ }^{12}$ Een van de manieren om $\mathrm{CO}_{2}$-uitstoot te reduceren is een circulaire economie. Chris Backes heeft geconcludeerd dat de huidige weten regelgeving onvoldoende bijdraagt aan het bereiken van een circulaire economie en dat deze zodoende aanpassing behoeft. Daartoe doet hij onder andere voorstellen ten aanzien van de Omgevingswet, de Kaderrichtlijn afvalstoffen, BBT-documenten en de Ecodesign-richt-

8. Na de afronding van dit artikel werd bekend dat de vier coalitiepartijen en drie oppositiepartijen een akkoord hebben bereikt over de klimaatwet.

9. Kamerstukken II 2017/18, 32 813, nr. 157

10. Dit is toegevoegd conform de motie-Yesilgöz-Zegerius en Jetten (Kamerstukken II 2017/18, 30 196, nr. 595). Het Klimaatberaad ziet toe op de samenhang tussen de afspraken die raken aan wet- en regelgeving, aldus de Kamerbrief van 12 juni 2018.

11. Raad van State, Klimaatbeleid in wetgeving en akkoorden. Verslag van de Expertbijeenkomst van de Raad van State op 20 maart 2018, mei 2018, i.h.b. J.J. van Dijk, Bestuursakkoord: noodzakelijk, maar niet voldoende, p. 88 en 91.

12. V.M.Y. van 't Lam, Integreren we in de toekomst ook wetgeving op het gebied van klimaat en energie? TO 2017, afl. 3, p. 99-101. 
lijn. ${ }^{13}$ De ervaringen in de praktijk ten aanzien van energiebesparing illustreren mijns inziens dat het een uitdagende opgave is voor de wetgever om effectieve regelgeving in te voeren die bijdraagt aan de reductie van $\mathrm{CO}_{2}{ }^{14} \mathrm{Zo}$ werd en wordt energiebesparing afgedwongen via convenanten, zoals de Meerjarenafspraken Energie-efficiëntie ETS-inrichtingen (het MEE-convenant) en Meerjarenafspraken energie-efficiëntie 2001-2020 (MJA3). Ik sluit daarom niet uit dat er niet alleen regelgeving wordt aangepast of geschreven om een $\mathrm{CO}_{2}$-reductie te bereiken, maar dat daartoe ook convenanten zullen worden gesloten. ${ }^{15}$ Het zou niet verbazen als die bovendien erg relevant zullen zijn. ${ }^{16}$ Ook zij nog gewezen op subsidieregelingen die zien op duurzaamheid. ${ }^{17}$ Voorts blijkt dat de versnipperde regelgeving die op energiebesparing ziet, niet goed wordt nageleefd/gehandhaafd. Een treffend voorbeeld biedt een voorschrift in het Activiteitenbesluit milieubeheer dat ziet op energiebesparing (art. 2.15). Op grond van dat artikel moeten bepaalde bedrijven alle energiebesparingsmaatregelen treffen die zich binnen vijf jaar terugverdienen. ${ }^{18}$ De bestuursrechtelijke geschillen over dit artikel laten zien dat het een bepaling is die niet gemakkelijk is uit te leggen; welke maatregelen mogen nu precies worden afgedwongen en hoe wordt de terugverdientijd precies berekend? Een recent voorbeeld is een uitspraak van de Afdeling bestuursrechtspraak van de Raad van State, waaruit volgt dat ten onrechte handhavend is opgetreden tegen de Aldi vanwege een overtreding van voornoemde verplichting door het niet plaatsen van dubbelglasdeuren ter afdekking van de verticale koelmeubelen. ${ }^{19}$ Art. 2.15 wordt aangepast, omdat blijkt dat de handhaving van dat artikel lastig is en tekortschiet. ${ }^{20}$ Daarnaast geldt voor 'grote ondernemingen' een energieauditverplichting op grond van de Tijdelijke regeling implementatie artikelen 8 en 14 Richtlijn energie-efficiëntie. Ook de naleving van deze verplichting liet aanvankelijk te wensen over. ${ }^{21} \mathrm{Ik}$ verwacht daarom dat het voor de wetgever een uitdagende opgave

13. Chr. Backes, Law for a Circulair Economy (oratie Utrecht), Den Haag: Eleven International Publishing 2017.

14. Zie over de uitdagende opgave voor wetgeving t.a.v. klimaat en energie ook Raad van State 2018, p. 21-22.

15. Zie ook M. de Rijke, Europese doelstellingen voor energie-efficiëntie: aanvullende energiebesparingsmaatregelen vereist, NTeR 2018, afl. $1 / 2$.

16. Daarbij moet er volgens Gerbrandy voor worden gewaakt dat er een strijd ontstaat met het mededingingsrecht, zie Raad van State 2018, p. 23 en de bijdrage van A. Gerbrandy, Klimaatakkoord(en) en het mededingingsrecht, p. 55 e.v.

17. Zie o.a. E.M.N. Noordover \& A. Drahmann, Subsidies voor duurzame initiatieven, Bb 2018/33.

18. Het gaat om A- en B-inrichtingen. Op grond van art. 5.12 Bor mogen aan een omgevingsvergunning voor bedrijven die meedoen aan het emissiehandelssysteem geen emissiegrenswaarden t.a.v. $\mathrm{CO}_{2}$ noch voorschriften t.a.v. de bevordering van een zuinig gebruik van energie worden opgelegd.

19. ABRvS 23 mei 2018, ECLI:NL:RVS:2018:1688

20. Zie www.internetconsultatie.nl/wijzigingactiviteitenbesluitmilieubeheer. V.M.Y. van 't Lam \& E.C. van der Maden, De informatieplicht en de verplichting tot het treffen van energiebesparende maatregelen uit het Activiteitenbesluit onder de loep, Bb 2018/37.

21. Kamerstukken II 2016/17, 31 209, nr. 213. is om regelgeving te maken ten aanzien van energiebesparing die goed wordt nageleefd en ook handhaafbaar is. Mogelijk kunnen niet alleen de hiervoor genoemde, maar ook andere ervaringen ten aanzien van energiebesparing inzicht geven voor de toekomstige regelgeving voor de langetermijntransitie. Mijns inziens is aandacht voor wetgeving niet alleen nodig om de gestelde doelen te bereiken. Ook moet worden voorkomen dat bestaande regelingen - met goede intenties - 'oneigenlijk' worden gebruikt om klimaat- en energiedoelen te bereiken. Ook om die reden verdient het aanbeveling dat er specifieke (handhaafbare) regelgeving wordt geschreven die ziet op energie en klimaat. 